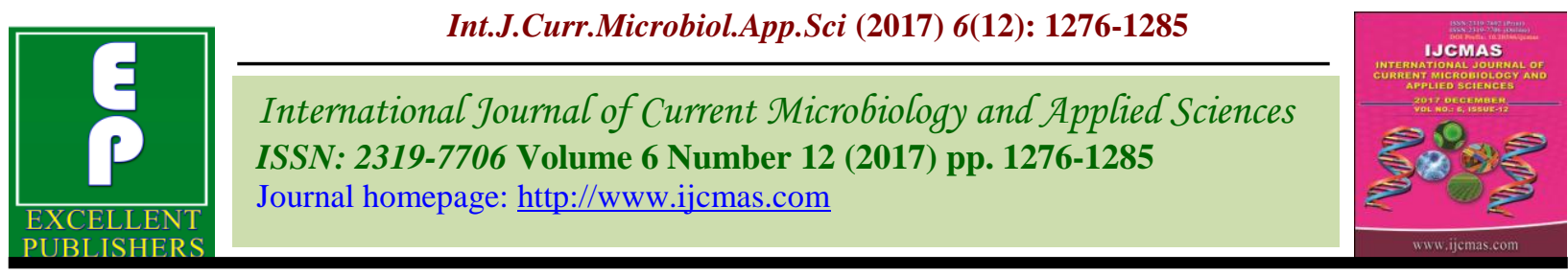

Original Research Article

https://doi.org/10.20546/ijcmas.2017.612.144

\title{
Genetic Variability and Divergence Studies for Yield Component Traits in Grain Amaranth (Amaranthus spp.)
}

\author{
B.M. Lokeshkumar* and Niranjana Murthy
}

Department of Genetics and Plant Breeding, University of Agricultural Sciences,

Bengaluru-560065, Karnataka, India

*Corresponding author

\section{A B S T R A C T}

\begin{tabular}{|l|}
\hline Ke y w o r d s \\
Grain amaranth, \\
Amaranthus, \\
Pseudocereal, Growth \\
and yield traits, \\
Variability, Diversity, \\
K-mean clustering, \\
and standardized \\
range.
\end{tabular}

Grain amaranth is a protein rich psuedocereal, assumes an important position in terms of quality breeding activities. Systematic characterization, evaluation and utilization of the potential germplasm in the crop are prerequisite to any crop improvement. The investigation on genetic variability and genetic divergence with respect to yield component traits estimated using 105 germplasm during Kharif 2013 at University of Agricultural Sciences, Bengaluru. A high phenotypic coefficient of variation (PCV) and genotypic coefficient of variation (GCV) was observed for all the traits except for, chlorophyll content (SPAD chlorophyll meter reading), panicle width and 1000 seed weight. Heritability estimates were high for all the characters studied. High genetic advance as per cent mean (GAM) was registered for most of the traits except for 50 per cent flowering, 1000 seed weight and days to maturity. The divergence studies using K-means clusters analysis approach has grouped the test materials into seven clusters. Cluster V was the largest comprising of 25 genotypes while cluster VII was solitary with only one genotype. Inter-cluster distance was maximum between clusters II and cluster VII. The genotypes IC095204, SKGPA-70 and IC095244 superior over the standard check for grain yield.

\section{Introduction}

Grain amaranth is fast growing, dicotyledonous, belonging to genus Amaranthus and family Amaranthaceae. Grain amaranth is a nutritionally potential photo-synthetically efficient $\mathrm{C}_{4}$ plant which is highly adaptable to various climatic conditions. In addition, these crops are well adapted to harsh environmental conditions and are therefore suitable for cultivation on marginal soils. The amaranth grain is one of the valuable foods as it has high protein content and well balanced amino acid profile (Gamel, et al., 2004). Chemical composition and nutritional value of grain amaranth
(Dodok et al., 1994) confirms its high potential for use as human and animal nutrition as well as medicine (Teutenico and Knorr, 1985). With the increasing need of exploring alternate sources of food, it is necessary to accelerate and expand the production of amaranthus.

The basic objectives of any breeding program are enhancement of grain yield and quality. Availability of sufficient amount of genetic variability among the breeding material is prerequisite to develop high yielding cultivars. In this regard, identification of 
superior genotypes with desirable traits and their subsequent use in breeding program would be helpful in successful varietals improvement program. Analysis of genetic variability and genetic diversity among the traits contributing to yield would be of great importance in planning a successful breeding program. The choice of suitable parents is of paramount importance for a planned hybridization programme. Hence, it is imperative to identify the best parents with wide genetic divergence for characters of economic importance, so that they can be utilized in breeding programmes to produce desirable recombinants. Development of highyielding cultivars requires a thorough knowledge of the existing genetic variation for yield and its components. The observed variability is a combined with the help of suitable parameters such as genetic coefficient of variation, heritability estimates and genetic advance are absolutely necessary to start an efficient breeding program. The objectives of the present study were to assess genetic diversity and genetic variability of grain amaranth germplasm for yield contributing traits.

\section{Materials and Methods}

The present investigation was conducted at All India Coordinated Research Network on Underutilized Crops, Main Research Station, Hebbal, University of Agricultural Sciences, Bengaluru during Kharif 2013. The experimental material comprised of 105 grain amaranth genotypes (Table 1). The experiment was laid out in an Augmented design (Federer, 1956) with 5 compact blocks. Each block was comprised of twenty one genotypes and four check varieties. All the checks were repeated randomly in all the blocks, while the genotypes were unreplicated. Each genotype was sown in two rows of 1.5 meters length each with a spacing of 45 centimeters between the rows.
Recommended agronomic practices and plant protection measures were followed to raise good crop. Five plants from each genotype were selected randomly for gathering observations on 14 characters i.e. SPAD chlorophyll meter reading (SCMR), days to $50 \%$ flowering, days to maturity, plant height $(\mathrm{cm})$, stem girth $(\mathrm{cm})$, panicle length $(\mathrm{cm})$, panicle width $(\mathrm{cm})$, total dry weight of leaf $(\mathrm{g}$ plant $\left.^{-1}\right)$, dry weight of stem $\left(\mathrm{g}\right.$ plant $\left.{ }^{-1}\right)$, dry weight of panicle $\left(\mathrm{g}\right.$ plant $\left.{ }^{-1}\right)$, total dry matter production $\left(\mathrm{g}\right.$ plant $\left.^{-1}\right)$, harvest index, 1000 seed weight $(\mathrm{g})$, Grain yield $\left(\mathrm{g}\right.$ plant $\left.{ }^{-1}\right)$.

Genetic variability parameters such as, mean, range, phenotypic coefficient of variation and genotypic coefficient of variation were computed (Burton and De vane, 1953), broadsense heritability (Lush, 1945) and expected genetic advance as per cent mean were estimated (Johnson et al., 1955) using adjusted trait mean of each of the germplasm using INDOSTAT v9.2 software. Nonhierarchical Euclidean cluster analysis based on K-means method was performed using SPSS software version 16 for assessing the genetic divergence among the germplasm accessions (Mac Queen, 1967).

\section{Results and Discussion}

The analysis of variance revealed significant difference among the genotypes for most of the traits at $\mathrm{P}=0.01$ except the traits like SCMR, panicle width and 1000 seed weight which differed significantly at $\mathrm{P}=0.05$, indicating the existence of sufficient variation in the material studied, as shown in Table 2. The results pertaining to mean, range, GCV, PCV, Heritability $\left(h^{2}\right)$ in broad sense and GAM were estimated for all the characters and are presented in Table 3.

The estimates of standardized range provide clues about the occurrence of accessions with extreme expression which varied with the 
trait. However, standardized range per se does not reflect variability in the expression of all the accessions. The values of phenotypic coefficient of variation were higher than those of genotypic coefficient of variation for all the characters studied. Similar results in grain amaranth were obtained by Ramesh et al., (2013), Sravanthi et al., (2012) and Venkatesh (2012). The SPAD chlorophyll meter value at 45 days ranged from 6.43 (genotype VL-344) to 38.3 (genotype IC035633) with a mean value of 17.28 and exhibited moderate GCV and high PCV, heritability and GAM. Genotypes showed wide range of variation from 29 days to 44 days for $50 \%$ flowering with a mean value of 37 days, genotype Annapurna was the earliest to flower.

Among the genotypes, heritable portion of variance (broad sense) was high and GAM is moderate for days to 50 per cent flowering. Days to maturity ranged from 79 (Annapurna) to 100 (SKGPA64, IC035638) days with mean value of 91 days. Low PCV and GCV with high heritability and low GAM was observed for the trait days to maturity. Hiremath (2005) and Venkatesh (2012) reported high heritability for days to 50 per cent flowering, days to maturity.

The mean plant height of the genotypes ranged between $23.37 \mathrm{~cm}$ (SKGPA81) to $140.72 \mathrm{~cm}$ (SKGPA71) with a mean value of $76.71 \mathrm{~cm}$. High variability for plant height noticed, which was indicated by high PCV and GCV, heritability and GAM. Range of $0.46 \mathrm{~cm}$ (SKGPA81) to $1.74 \mathrm{~cm}$ (SKGPA63) with a mean of $1.1 \mathrm{~cm}$ and high PCV, GCV, heritability and GAM was observed for the trait stem girth. The values ranged from 10.67 $\mathrm{cm}$ (SKGPA81) to $48.31 \mathrm{~cm}$ (SKGPA69) with a mean of $31.59 \mathrm{~cm}$ and high GCV, PCV heritability and GAM observed for panicle length. Venkatesh (2012) and Sravanthi et al., (2012) observed higher PCV and GCV for plant height, girth and panicle length. The observed data indicated the wide range of variability for total dry matter at maturity from $22.57 \mathrm{~g} \mathrm{plant}^{-1}$ (SKGPA 79) to $131.15 \mathrm{~g}$ plant $^{-1}$ (SKGPA 88) with a mean value of $64.43 \mathrm{~g}$ plant $^{-1}$. PCV, GCV, heritability, and GAM were also high for total dry matter content. Minimum grain yield in IC120670 $\left(7.33 \mathrm{~g} \mathrm{plant}^{-1}\right)$ and maximum grain yield in IC095244 (32.33 g plant 1 ) with a mean of $14.16 \mathrm{~g}$ plant $^{-1}$ were recorded. The genotypes showed high genetic variability was indicated by high GCV (30.47 per cent), PCV (31.98 per cent) and high heritability (90.77 per cent) and genetic advance as per cent of mean (59.808) was noticed for economically important trait grain yield.

The grain yield which is an important trait showed high phenotypic and genotypic coefficient of variation which is in agreement with several earlier reports of Verma et al., (2001), Venkatesh (2012), Sravanthi et al., (2012) and Ramesh et al., (2013).The characters showing high range of variation have more scope for improvement. In the present study all the characters (except 1000 seed weight) exhibited high variability as evident from the ranges of mean values, indicated the presence of high variability and thus offering greater scope for selection and improvement. The present and earlier results suggest the availability of variability for grain yield in grain amaranth and scope to improve this economic trait through selection.

According to Panse and Khargonkar (1957), if the heritability of a particular character is high in a specific environment coupled with low GAM, then it is mainly due to non -additive gene action, whereas the heritability is due to additive gene action if, high heritability is associated with high GAM. The present results on genetic variability, heritability and genetic advance as percent of mean for many traits in grain amaranth suggest that a careful exercise needs to be done before attempting to improve any desired traits. 
Table.1 List of genotypes and check varieties of grain amaranth used in the study

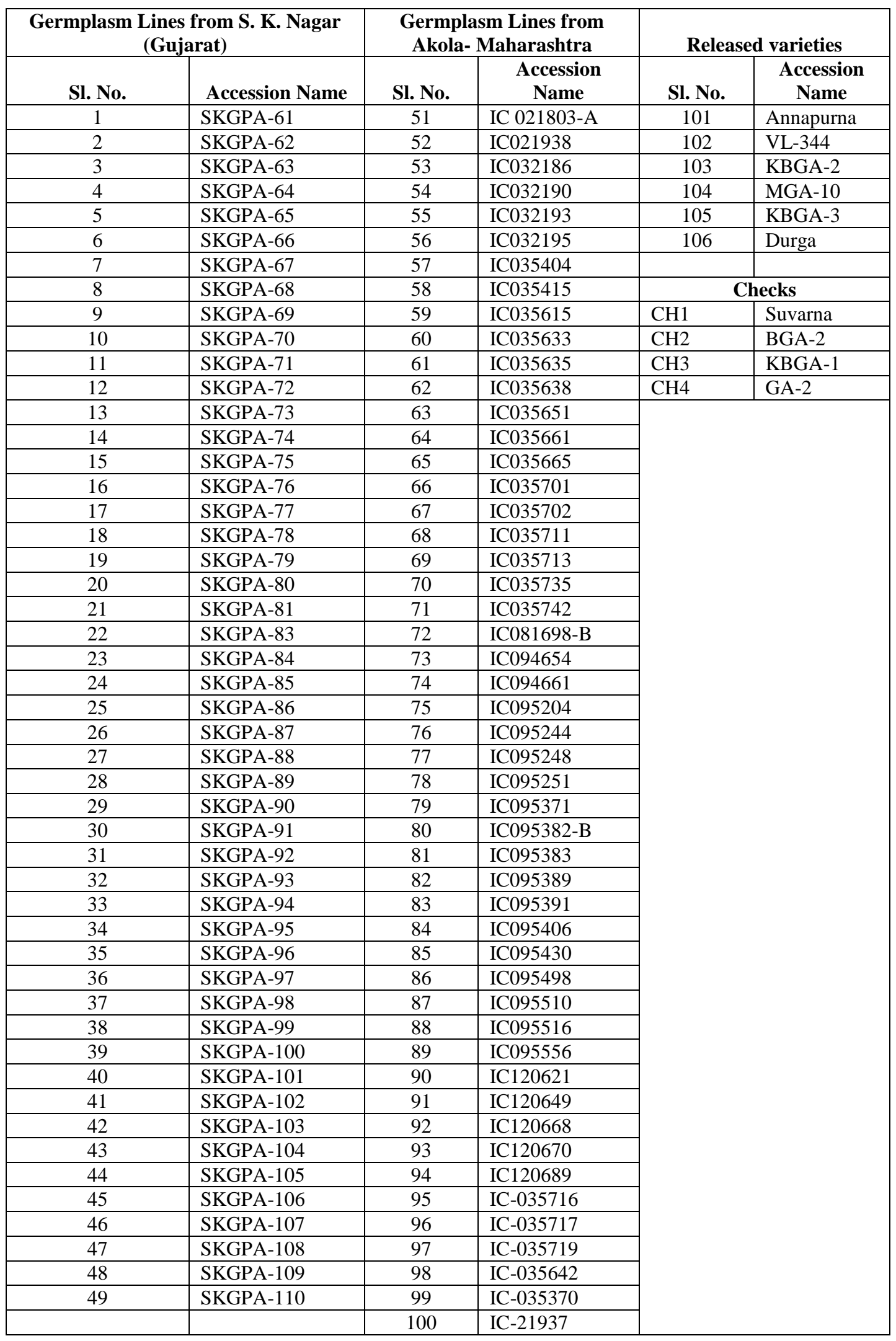


Table.2 Analysis of variance for growth and yield traits in 105 genotypes of grain amaranth

\begin{tabular}{|c|c|c|c|c|c|c|}
\hline Source of variation & Blocks (b) & $\begin{array}{c}\text { Entries (e) } \\
\text { (Germplasm } \\
\text { accessions + } \\
\text { check entries) }\end{array}$ & $\begin{array}{c}\text { Check } \\
\text { entries (c) }\end{array}$ & $\begin{array}{c}\text { Germplasm } \\
\text { accessions (g) }\end{array}$ & $\begin{array}{c}\text { Accessions } \\
\text { v/s Check } \\
\text { varieties }\end{array}$ & Error \\
\hline Df & 4 & 108 & 3 & 104 & 1 & 12 \\
\hline SCMR at 45 days & 9.07 & $20.69^{*}$ & 1.18 & $20.79^{*}$ & $69.65^{* *}$ & 7.38 \\
\hline Days to $50 \%$ flowering & 0.69 & $18.03^{* *}$ & 1.33 & $14.69^{* * *}$ & $415.21^{* *}$ & 0.83 \\
\hline Days to maturity & 2.70 & $18.02^{* *}$ & $58.98^{* *}$ & $16.96^{* *}$ & $5.08^{*}$ & 1.07 \\
\hline Plant height & $250.93^{* *}$ & $717.76^{* * *}$ & $957.43^{\text {** }}$ & $610.64^{* * *}$ & $11139.52^{* *}$ & 32.81 \\
\hline Stem girth & 0.005 & $0.093^{* *}$ & $0.25^{* *}$ & $0.073^{* *}$ & $1.689^{* *}$ & 0.01 \\
\hline Panicle length & 20.37 & $71.26^{* *}$ & 4.34 & $68.34^{* *}$ & $575.57^{* *}$ & 6.73 \\
\hline Panicle width & 7.74 & $21.39^{* *}$ & $30.83^{*}$ & $18.99^{*}$ & $242.68^{* *}$ & 5.62 \\
\hline Dry weight of leaf & 7.49 & $63.41^{* *}$ & $209.31^{* *}$ & $46.42^{* *}$ & $1392.99^{* *}$ & 5.15 \\
\hline Dry weight of panicle & 14.50 & $284.93^{* *}$ & $1178.32^{* * *}$ & $190.03^{* * *}$ & $7474.28^{* *}$ & 15.84 \\
\hline Dry weight of stem & $19.04^{*}$ & $166.21^{* *}$ & 11.15 & $142.58^{* * *}$ & $3089.42^{* *}$ & 5.53 \\
\hline Total dry weight & 44.55 & $992.22^{* *}$ & $1929.76^{* *}$ & $665.39^{* * *}$ & $32169.79^{* *}$ & 25.56 \\
\hline 1000 seed weight & $0.06^{*}$ & $0.041^{*}$ & $0.06^{*}$ & $0.04^{*}$ & 0.01 & 0.017 \\
\hline Harvest Index & $0.01 * *$ & $0.003 * *$ & $0.01 * *$ & $0.002 * *$ & $0.01 * *$ & 0.00 \\
\hline Grain yield & $26.96^{* *}$ & $49.87^{* *}$ & $529.18^{* * *}$ & $23.36^{* *}$ & $1369.18^{* *}$ & 1.89 \\
\hline
\end{tabular}

Table.3 Descriptive statistics for growth and yield traits in 105 genotypes of grain amaranth

\begin{tabular}{|c|c|c|c|c|c|c|c|c|}
\hline \multirow[b]{2}{*}{ Characters } & \multirow[b]{2}{*}{ Mean \pm SE } & \multicolumn{2}{|c|}{ Range } & \multirow{2}{*}{$\begin{array}{c}\text { Standardized } \\
\text { range (SR) }\end{array}$} & \multicolumn{2}{|c|}{$\begin{array}{c}\text { Co-efficient of } \\
\text { variation }\end{array}$} & \multirow{2}{*}{$\begin{array}{c}\mathbf{h}^{2}(\mathbf{b s}) \\
\%\end{array}$} & \multirow[b]{2}{*}{ GAM } \\
\hline & & Max & Min & & GCV\% & PCV\% & & \\
\hline SCMR at 45 days & $17.28 \pm 0.44$ & 38.3 & 6.43 & 1.84 & 19.73 & 25.22 & 61.18 & 31.79 \\
\hline $\begin{array}{l}\text { Days to } 50 \% \\
\text { flowering }\end{array}$ & $37.63 \pm 0.37$ & 44 & 29 & 0.4 & 9.21 & 9.52 & 93.51 & 18.35 \\
\hline Days to maturity & $91.20 \pm 0.40$ & 100 & 79 & 0.23 & 4.07 & 4.22 & 92.82 & 8.07 \\
\hline Plant height & $76.71 \pm 2.41$ & 140.72 & 23.37 & 1.53 & 29.17 & 30.11 & 93.85 & 58.21 \\
\hline Stem girth & $1.10 \pm 0.03$ & 1.74 & 0.46 & 1.15 & 21.51 & 23 & 87.38 & 41.41 \\
\hline Panicle length & $31.59 \pm 0.79$ & 48.31 & 10.67 & 1.19 & 23.07 & 24.48 & 88.8 & 44.78 \\
\hline Panicle width & $17.16 \pm 0.43$ & 28.66 & 6.6 & 1.29 & 19.83 & 24.17 & 67.31 & 33.51 \\
\hline Dry weight of leaf & $11.16 \pm 0.66$ & 31.56 & 2.67 & 2.59 & 53.57 & 57.31 & 87.4 & 103.18 \\
\hline Dry weight of panicle & $29.90 \pm 1.34$ & 74.34 & 7.33 & 2.24 & 41.09 & 43.19 & 90.5 & 80.52 \\
\hline Dry weight of stem & $23.37 \pm 1.16$ & 51.88 & 4.86 & 2.01 & 46.64 & 47.72 & 95.54 & 93.91 \\
\hline Total dry weight & $64.43 \pm 2.51$ & 131.15 & 22.57 & 1.69 & 36.55 & 37.38 & 95.59 & 73.61 \\
\hline 1000 seed weight & $1.48 \pm 0.02$ & 2.24 & 0.91 & 0.9 & 9.74 & 13.09 & 55.39 & 14.93 \\
\hline Harvest Index & $0.19 \pm .005$ & 0.3 & 0.09 & 1.1 & 23.38 & 23.75 & 96.00 & 47.41 \\
\hline Grain yield & $14.16 \pm 0.47$ & 32.33 & 7.33 & 1.77 & 30.47 & 31.98 & 90.77 & 59.81 \\
\hline
\end{tabular}


Table.4 Sources and clustering of 105 genotypes of grain amaranth in seven clusters

\begin{tabular}{|c|c|c|}
\hline Clusters & Number of accessions & Name of the genotypes \\
\hline I & 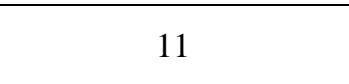 & $\begin{array}{l}\text { IC-21937, SKGPA-84, SKGPA-89, SKGPA-98, SKGPA-99, IC032190, } \\
\text { IC032195, IC095510, IC120649, KBGA-3, Durga. }\end{array}$ \\
\hline II & 18 & $\begin{array}{l}\text { SKGPA-61, SKGPA-62, SKGPA-77, SKGPA-78, SKGPA-79, SKGPA-81, } \\
\text { SKGPA-86, SKGPA-101, SKGPA-103, SKGPA-104, IC035635, IC035651, } \\
\text { IC035665, IC095383, IC095389, IC095391, IC095406, IC095498. }\end{array}$ \\
\hline III & 4 & SKGPA-71, SKGPA-85, SKGPA-90, IC-035717. \\
\hline IV & 24 & $\begin{array}{l}\text { SKGPA-64, SKGPA-66, SKGPA-72, SKGPA-74, SKGPA-75, SKGPA-96, } \\
\text { SKGPA-105, SKGPA-107, SKGPA-110, IC 02180, IC032193, IC035415, } \\
\text { IC035702, IC035742, IC081698, IC094654, IC095248, IC095251, IC095382, } \\
\text { IC095430, IC095516, IC-035370, KBGA-2, MGA-10. }\end{array}$ \\
\hline V & 25 & $\begin{array}{l}\text { SKGPA-65, SKGPA-73, SKGPA-76, SKGPA-80, SKGPA-83, SKGPA-87, } \\
\text { SKGPA-94, SKGPA-95, SKGPA-97, SKGPA-100, SKGPA-102, SKGPA-106, } \\
\text { SKGPA-108, SKGPA-109, IC035404, IC035615, IC035633, IC035638, } \\
\text { IC035661, IC035713, IC120621, IC120668, IC120670, IC-035642, Annapurn. }\end{array}$ \\
\hline VI & 22 & $\begin{array}{l}\text { SKGPA-63, SKGPA-67, SKGPA-68, SKGPA-69, SKGPA-70, SKGPA-91, } \\
\text { SKGPA-92, SKGPA-93, IC021938, IC032186, IC035701, IC035711, } \\
\text { IC035735, IC094661, IC095204, IC095244, IC0953719, IC095556, IC120689, } \\
\text { IC-035716, IC095556, IC120689. }\end{array}$ \\
\hline VII & 1 & SKGPA-88. \\
\hline
\end{tabular}

Table.5 Estimates of average inter-cluster distances for quantitative traits in grain amaranth

\begin{tabular}{|c|c|c|c|c|c|c|c|}
\hline Cluster & I & II & III & IV & V & VI & VII \\
\hline I & & 60.81 & 72.45 & 29.77 & 34.62 & 43.06 & 81.50 \\
\hline II & 60.81 & & 128.02 & 58.59 & 31.71 & 98.29 & 140.76 \\
\hline III & 72.45 & 128.02 & & 72.47 & 97.42 & 37.06 & 35.17 \\
\hline IV & 29.77 & 58.59 & 72.47 & & 28.64 & 45.43 & 91.91 \\
\hline V & 34.62 & 31.71 & 97.42 & 28.64 & & 69.27 & 112.20 \\
\hline VI & 43.06 & 98.29 & 37.06 & 45.43 & 69.27 & & 53.32 \\
\hline VII & 81.50 & 140.76 & 35.17 & 91.91 & 112.20 & 53.32 & \\
\hline
\end{tabular}

Table.6 Cluster mean values and percent contribution for growth and yield traits in 105 genotypes of grain amaranth

\begin{tabular}{|c|c|c|c|c|c|c|c|c|c|}
\hline \multirow[t]{2}{*}{ Characters } & \multicolumn{7}{|c|}{ Cluster Means } & \multirow{2}{*}{$\begin{array}{c}\text { Percent } \\
\text { contribution }\end{array}$} & \multirow[t]{2}{*}{$F$ value } \\
\hline & I & II & III & IV & $\mathbf{V}$ & VI & VII & & \\
\hline SCMR at 45 days & 16.97 & 13.27 & 21.18 & 17.39 & 16.93 & 20.19 & 19.17 & 4.07 & $5.50 * *$ \\
\hline Days to $50 \%$ flowering & 37.55 & 37.72 & 40.00 & 38.46 & 36.32 & 37.86 & 35.00 & 1.17 & $1.02 *$ \\
\hline Days to maturity & 92.18 & 94.56 & 91.00 & 90.33 & 90.04 & 90.41 & 88.00 & 0.62 & $3.20 * *$ \\
\hline Plant height & 69.12 & 41.36 & 129.41 & 86.64 & 64.64 & 101.08 & 113.79 & 9.81 & $101.19 * *$ \\
\hline Stem girth & 1.06 & 0.77 & 1.47 & 1.20 & 1.01 & 1.34 & 1.40 & 5.82 & $20.93 * *$ \\
\hline Panicle length & 30.76 & 19.78 & 42.19 & 36.18 & 28.24 & 38.23 & 38.61 & 6.38 & $37.08^{* * *}$ \\
\hline Panicle width & 16.66 & 13.30 & 21.45 & 17.65 & 16.09 & 20.28 & 22.00 & 4.84 & $7.41 * *$ \\
\hline Dry weight of leaf & 8.69 & 5.43 & 20.34 & 13.20 & 6.82 & 17.32 & 28.86 & 16.24 & $20.99 * *$ \\
\hline Dry weight of panicle & 41.99 & 14.72 & 57.47 & 25.10 & 25.34 & 39.66 & 74.34 & 14.42 & $39.08 * *$ \\
\hline Dry weight of stem & 25.20 & 12.64 & 29.51 & 22.43 & 15.62 & 39.72 & 27.95 & 10.17 & $30.73^{* * *}$ \\
\hline Total dry weight & 75.88 & 32.79 & 107.31 & 60.73 & 47.79 & 96.70 & 131.15 & 12.26 & $129.14 * *$ \\
\hline 1000 seed weight & 1.43 & 1.46 & 1.48 & 1.49 & 1.49 & 1.48 & 1.43 & 0.48 & 0.13 \\
\hline Harvest Index & 0.15 & 0.25 & 0.16 & 0.20 & 0.19 & 0.16 & 0.11 & 6.93 & $13.13^{* *}$ \\
\hline Grain yield & 13.40 & 10.76 & 20.75 & 14.72 & 11.33 & 18.58 & 17.00 & 6.81 & $12.09 * *$ \\
\hline
\end{tabular}




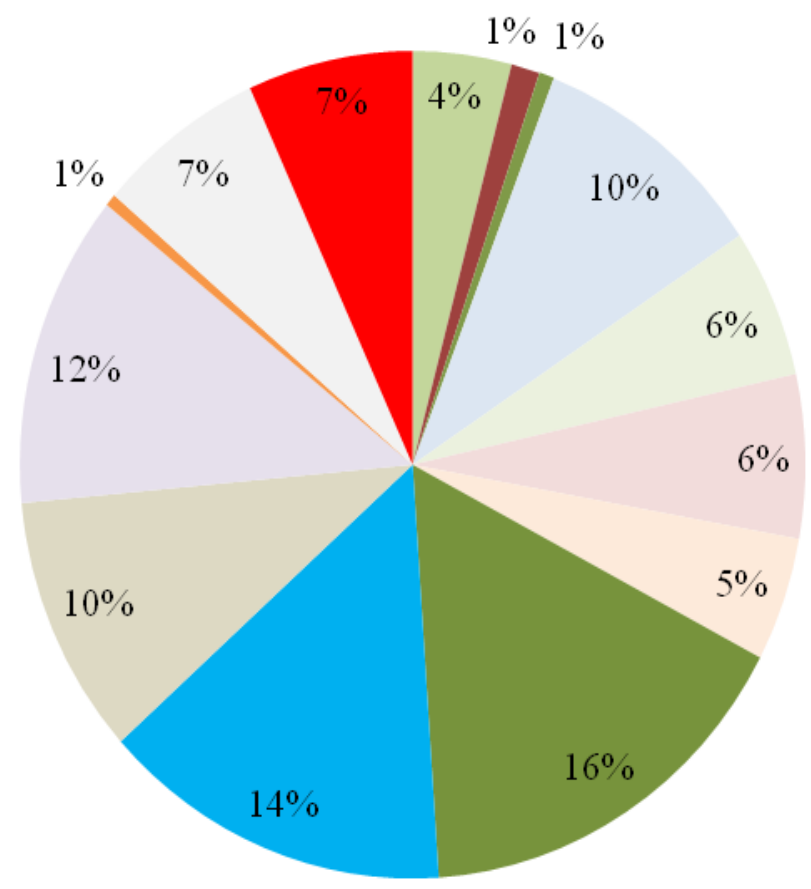

$\square$ SCMR at 45 days

-Days to $50 \%$ flowering

- Days to maturity

Plant height

Stem girth

Panicle length

Panicle width

- Dry weight of leaf

- Dry weight of panicle

Dry weight of stem

Total dry weight

- Harvest Index

1000 seed weight

- Grain yield

Fig. 1: Percent contribution towards genetic diversity.

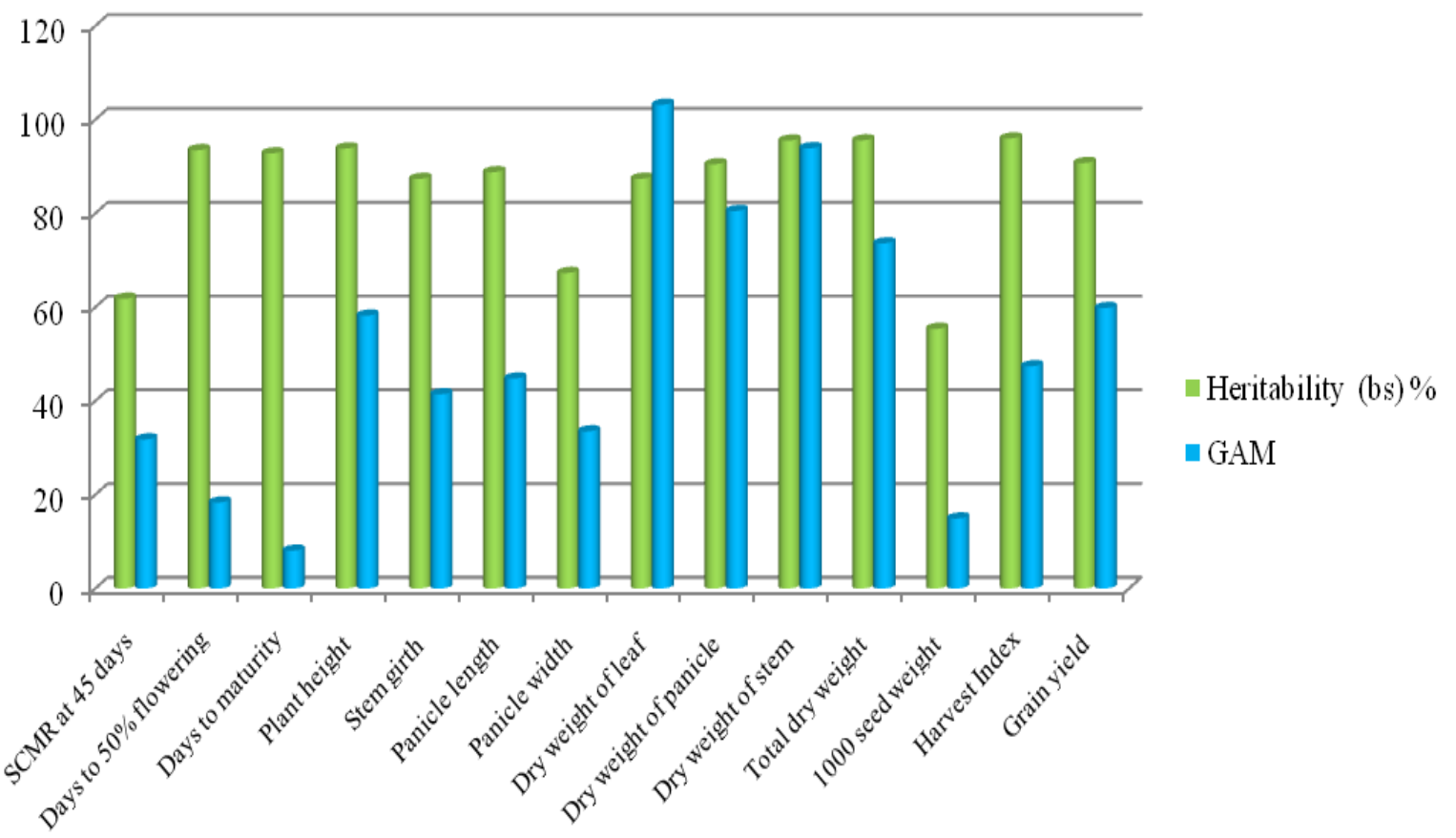

Fig.2 Heritability (bs) and GAM for growth and yield traits in 105 genotypes of grain amaranth. 
Genetic relationship among the genotypes can be measured by similarity and dissimilarity of any number of quantitative characters assuming that the differences between the characters of genotypes reflect the divergence of genotypes. The identification of accessions contrasting for various traits of economic importance is a prerequisite for eliciting such information. Cluster analysis helps in grouping of accessions sharing similar characters in different clusters and to identify genetically diverse and desirable genotypes. The number of the genotypes, name of the genotypes and the cluster to which it belongs are mentioned in the Table 4. This grouping reflects the wide genetic divergence among the genotypes.

Maximum number of genotypes were grouped in cluster V (25 genotypes) followed by cluster IV (24 genotypes), cluster VI (22 genotypes), cluster II (18 genotypes), cluster I (11 genotypes), cluster III (4 genotypes), and only one genotype was grouped in to cluster VII. Clusters II and VII were most diverse with maximum (140.76) followed by clusters II and III (128.02), clusters V and VII (112.2), clusters XI and XV (98.3), clusters III and V (97.42) inter-cluster distance (Table 5). Highly divergent genotypes would produce a broad spectrum of variable attributes enabling further selection and improvement. Intercluster distance between the cluster IV and V was the lowest (28.64) and cluster I and IV was (29.77) indicating that involved genotypes are closely related. The results of the inter-cluster distance indicated that presence of considerable diversity in 105 genotypes included in the present study. This could be the result of selection in different direction by nature and human forces which may suggest that maximum amount of heterosis may be expected in cross combination involving the genotypes of the most divergent clusters. Theoretically, crossing of genotypes belonging to the same cluster is not expected to yield superior hybrids or desirable segregants because they share common biochemical pathways. Hence, the chance of genetic advancement and exploitation of superior segregants may be limited when cross combination with in the cluster. However, a general notion in theory exists that the larger is the divergence between the genotypes, higher will be the heterosis (Falconer, 1981). Therefore, it would be desirable to attempt crosses between genotypes belonging to distant clusters for getting highly heterotic crosses. Further, heterosis cannot be exploited in a highly selffertilized crop. However, high heterosis might prove potential in isolating superior segregants in case of additive type of gene action.

The mean differences between clusters of all the traits were significant except for 1000 seed weight. It could be seen that clusters differ very much with respect to mean expression of various characters and thus reflect that the clusters formed are very distinct. Significance of $F$ value indicates the significant difference between the traits mean of clusters (Table 6).

The mean values was maximum in cluster II and minimum in cluster III for the traits SCMR at 45 days (13.27 to 21.18), plant height (41.36 to 129.41), panicle length (19.78 to 42.19$)$ and grain yield (10.76 to 20.75). The cluster II exhibit minimum and cluster VII exhibit maximum mean values for the traits Panicle width (13.30 to 22), dry weight of leaf (5.43 to 28.86), dry weight of panicle (14.72 to 74.34 ) and total dry weight (32.79 to 131.15). The same clusters cluster II and VII exhibit maximum and minimum mean values for the traits days to maturity (94.56 to 88) and harvest index ( 0.25 to 0.11 ) respectively. The mean values for days to $50 \%$ flowering 35.00 (cluster VII) to 40 (cluster III), stem girth 1.01 cluster V) to 
1.47(cluster III), dry weight of stem 12.64 (cluster II) to 39.72 (cluster VI) and 1000 seed weight 1.43 (cluster I) to 1.49 (cluster IV). Hence, crossing between these contrasting clusters may appears most promising to combine early flowering, early maturity, high biomass and considerable grain yield with high photosynthetic ability with high grain oil content. Hence, it is advisable to consider these genotypes belonging to distant clusters as parents for hybridization programme to combine desired characters. The results of genetic contribution towards diversity were depicted in Table 6 and Figure 1. The highest percent contribution towards diversity was made by the traits dry weight of leaf $(16.24 \%)$ and dry weight of panicle $(14.42 \%)$. These observations are in accordance with the reports of earlier workers Lohithaswa (1992), Joshi and Rana (1995) and Patgar (2003). The above results imply that in order to select genetically diverse genotypes for hybridization, the material should be screened for the important traits like, total biomass content, dry weight of leaf, dry weight of panicle, dry weight of stem, plant height and grain yield.

The Genotypes which surpassed the standard check variety Suvarna for different traits viz., SKGPA-88 for dry weight of plant at 95 days, IC095391, IC095406, SKGPA-100, SKGPA74 and SKGPA-78 for harvest index, and IC095204, SKGPA-70 and IC095244 for grain yield. All the traits exhibited high heritability and high GAM except days to 50\% flowering and 1000 seed weight (Figure 2). It implies that these traits are expected to controlled by additive gene action and direct selection for these traits is possible. As the inter-cluster distance between cluster II and cluster VII was maximum, effecting crosses between genotypes of cluster II with genotypes of cluster VII may yield wide spectrum of desirable transgressive segregants for different yield and yield contributing traits like Panicle width, dry weight of leaf, dry weight of panicle and total dry weight. Which may facilitate to identify superior genotypes to improve more than one characters simultaneously.

\section{Acknowledgment}

Department of Genetics and Plant Breeding, University of Agricultural Sciences Bengaluru Karnataka India -560065

\section{References}

Burton, G.W. and De vane, E.H., 1953, Estimating heritability in tall Festuca (Festuca arundinaceae) from replicated clonal material. Agron. J., 45: 478-481.

Dodok, L., Modhir, A.A., Halasova, G., Polacek, I. and Hozova, B., 1994, Importance and utilization of amaranth in food industry. Part I. Characteristic of grain and average chemical constitution of whole amaranth flour. Nahrung Food., 38: 378-381.

Falconer, D.S., 1981, Introduction to Quantitative Genetics, 2nd edition.

Federer, W. T., 1956, Augmented (or hoonuiaku) designs. Hawaii. Plant Research., 2: 191-208.

Gamel, T.H., Linssen, J.P., Alink, G.M., Mosallem, A.S. and Shekib, L.A. (2004) Nutritional Study of Raw and Popped Seed Proteins of Amaranthus caudatus L. and Amaranthus cruentus L. Journal of the Science of Food and Agriculture, 84: 1153-1158.

Hiremath, 2005, Genetic divergence in grain amaranth (Amaranthus spp.) germplasm. M.Sc.(Agri.) Thesis. University of Agricultural. Sciences Bangalore, 106pp.

Johnson, H.W., Robinson, H.F. and Comstock, R. F., 1955, Genotypic and phenotypic correlation in soybeans and their implication in selection. Agron. J., 
47: 477-483.

Joshi, B.D. and Rana, J. C., 1995, Genetic divergence in grain amaranth (Amaranthus hypochandriachus). Indian. J. Agric. Sci., 65(3): 605-60.

Lohitaswa, H.C., 1992, Genetic diversity and Character association in grain amaranth (Amaranhus spp). M.Sc. (Agri) Thesis, University of Agricultural Sciences Bangalore.

Lush, J. L., 1945, Heritability of quantitative characters in farm animals. Proc. $8^{\text {th }}$ Congress of Genetics, Heriditas, 35: 356-375.

Mac Queen, J. B., 1967, Some methods for classification and analysis of multivariate observations, proceedings of 5th Berkeley symposium on mathematical statistics and probability, Berkeley, University of California Press, 1: 281-297.

Panse, V.G. and Khargonkar, S.S., 1957, Genetics of quantitative characters in relation to plant breeding. Indian $J$. Genet., 17: 318-328.

Patgar, K.V., 2003, Evaluation of grain amaranth collection for productivity and quality traits (Amaranthus spp.), M.Sc. (Agri.) Thesis. University of
Agricultural Sciences Dharwad, 160pp.

Ramesh, K.S., Mohamed, G.Y. and Govindarasu, R., 2013, Studies on genetic parameters in grain amaranths (A. hypochondriacus) as influenced by plant densities. J. Plant Breed. Genet, 1: 34-42.

Sravanthi, V., Hameedunnisa, B., Neelum, S., and Medagam, T. R., 2012, Variance component analysis for grain yield and agro economic traits in grain amaranth (Amaranthus spp.). Adv. in Agric. Sci. and Eng. Res., 2(7): 233 - 244.

Teutonica, R.A. and Knorr, D., 1985, Amaranth composition, property and application of a rediscovered food. Crop. Food. Tech., 39: 49-61.

Venkatesh, L., 2012, Genetic variability and character association studies for growth and yield traits in grain amaranth (Amaranthus spp.). M.Sc. (Agri) Thesis of University of Agricultural Sciences Bangalore.

Verma, P.K., Gupta, S.N., Deen, M.K. and Shrama, G.D., 2001, Genetic variation, correlation and path co-efficient analysis for seed yield and quality characters in grain amaranth. Indian. $J$. Plant Genet. Resou, 14: 171-172.

\section{How to cite this article:}

Lokeshkumar, B.M. and Niranjana Murthy. 2017. Genetic Variability and Divergence Studies for Yield Component Traits in Grain Amaranth (Amaranthus spp.). Int.J.Curr.Microbiol.App.Sci. 6(12): 1276-1285. doi: https://doi.org/10.20546/ijcmas.2017.612.144 